\title{
Heterogeneity and Controlling Factors of Oxfordian Stage Carbonate Reservoir of Odjarly Gas Field, Amu Darya Basin
}

\author{
Bing-xiong $\mathrm{LU}^{1, \mathrm{a}, *}$ and Long-hua $\mathrm{MO}^{2, \mathrm{~b}}$ \\ ${ }^{1}$ College of Resources and Environment of Qinzhou University, Qinzhou 535000, Guangxi, china \\ ${ }^{2}$ Key Laboratory of New Processing Technology for Nonferrous Metals and Materials, Ministry of Education,Guilin \\ University of Technology, Guilin 541004, Guangxi,China \\ a10158258@qq.com, ${ }^{\mathrm{b}}$ mlh2008hit@163.com \\ * Bing-xiong Lu
}

\begin{abstract}
Based on core observation and thin section authentication, the control factors of Oxfordian Stage carbonate reservoir of Odjarly Gas field of Amu Darya Basin were discussed by comprehensive utilization of geological, drilling, seismic data etc. It was concluded that the carbonate reservoir developed mainly in grain limestone, oolitic limestone and conglomeratic bioclast limestone. Lithology controlled directly the porosity of reservoir, and the porosity of grain limestone was the highest. The analysis showed that the carbonate reservoir quality of the Oja-21 was under the control of the sedimentary microfacies. The oolite beach and microfacies of bioherm phase were the favorable to develop. The physical property of oolite beach was optimal, and it was the most favorable sedimentary microfacies of reservoir development. It concluded also that the heterogeneity of core section of carbonate reservoir of $\mathrm{Oja}$ - 21 was mainly controlled by lithology, sedimentary microfacies and diagenesis. As for the core section, the heterogeneity of reservoir could be summarized as interbedded heterogeneity and in-layer heterogeneity.
\end{abstract}

Keywords- carbonate reservoir; sedimentary facies; porosity; reservoir quality; heterogeneity

\section{INTRODUCTION}

The right bank of the Amu Darya is located in the Amu Darya basin of east Turkmenistan, The Oja-21 well of Odjarly gas field lies in Odjarly entrapment, which is located in the south slope of Sandy Clay lied in the centre of B block along the right bank of Amu darya. The Oja-21 well was drilled on October 26, 2009, finished on May 5, 2010, the depth is 4,152 meters, it was the deepest well of Jurassic reservoir at the right bank of the Amu Darya[1-3].

\section{CONTROLling FACTOR OF RESERVOIR}

Based on core observation, thin section authentication, physical property statistics and other analysis data, the development of Karloff- Oxfordian Stage carbonate reservoir in Oja-21 well lied in the right bank of Amu Darya was influenced by lithology, sedimentary facies, diagenesis and the late tectonic activity.

\section{A. The Control of the Lithology on the Development of Reservoir}

Based on thin section authentication and physical property statistics of reservoir, the reservoir mainly developed in grain limestone, especially in the oolitic limestone and conglomeratic bioclast limestone, while less in the granular micrite than grain limestone.

\section{B. The Relationship between Porosity and Lithology}

Based on the physical property analysis data of six roundtrips, the range of porosity was from $1.5 \%$ to $21.0 \%$, the average value was $9.2 \%$, the samples ranged $6.0 \%$ $12.0 \%$ accounted for $51.4 \%$ of the all samples of limestone, while the samples ranged $3 \% \sim 6 \%$ accounted for $22.9 \%$. According to the reservoir classification of CNPC (China National Petroleum Corporation) (as shown in Table I), the majority of the samples are mesopore and low porosity reservoir.

TABLE I. STANDARD OF CLASSIFICATION OF CARBONATE RESERVOIR OF CNPC

\begin{tabular}{|c|c|c|c|}
\hline classification & $\begin{array}{c}\text { Porosity } \\
(\%)\end{array}$ & $\begin{array}{c}\text { Permeability } \\
\left(10^{-3} \mathrm{um}^{2}\right)\end{array}$ & reservoir categories \\
\hline $\begin{array}{c}\text { high quality } \\
\text { ( I ) }\end{array}$ & $>16$ & $>100$ & $\begin{array}{c}\text { especially high porosity } \\
\text { and permeability }\end{array}$ \\
\hline $\begin{array}{c}\text { very good } \\
\text { ( II })\end{array}$ & $16 \sim 12$ & $100 \sim 10$ & $\begin{array}{c}\text { high porosity and } \\
\text { permeability }\end{array}$ \\
\hline $\begin{array}{c}\text { good } \\
\text { (III) }\end{array}$ & $12 \sim 6$ & $10 \sim 1$ & mesopore and permeability \\
\hline $\begin{array}{c}\text { medium } \\
\text { (IV) }\end{array}$ & $3 \sim 6$ & $1 \sim 0.1$ & $\begin{array}{c}\text { low porosity and } \\
\text { permeability }\end{array}$ \\
\hline $\begin{array}{c}\text { Poor } \\
\text { (V) }\end{array}$ & $<3$ & $<0.1$ & $\begin{array}{c}\text { especially low porosity and } \\
\text { permeability }\end{array}$ \\
\hline
\end{tabular}

The porosity was under the control of the lithology (as shown in Figurel and Table II). The porosity of grainstone was the highest, which ranged from $4.1 \%$ to $21.0 \%$, and the average value was $10.9 \%$. The porosity ranged mainly from $6.0 \%$ to $12.0 \%$, accounted for $51.4 \%$ of the total samples of grainstone, it is the most favorable reservoir to develop. The porosity of the granular micrite was higher also, which ranged from $1.5 \%$ to $16.5 \%$, the average value was $7.5 \%$. The porosity ranged mainly from $6.0 \%$ to $12.0 \%$, accounted for $51.4 \%$ of the total samples of granular micrite samples. 
The proportion of mesopore and high pore of grain limestone was greater than that of granular micrite, as shown in the histogram of two kinds of lithology (Figure1), so the reservoir performance of grain limestone was better than that of granular micrite.
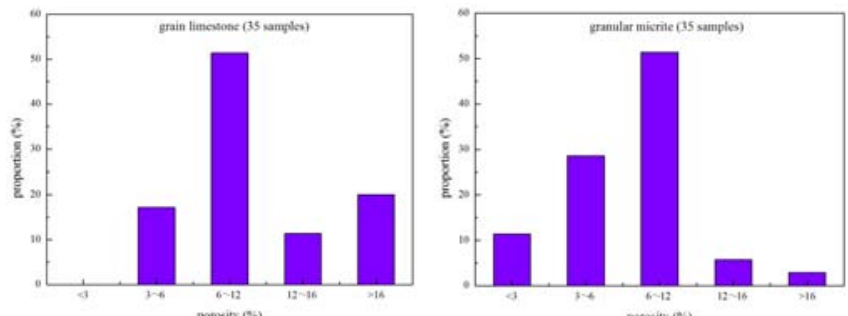

Figure 1. Proportion of porosity of Wells Karloff- Oxfordian Stage reservoir

TABLE II. POROSITY OF DIFFERENT LITHOLOGY OF OJA-21

\begin{tabular}{|c|c|c|c|}
\hline \multicolumn{2}{|c|}{ lithology } & grain limestone & granular micrite \\
\hline \multirow{3}{*}{ porosity(\%) } & $\min$ & 4.1 & 1.5 \\
\cline { 2 - 4 } & $\max$ & 21 & 16.5 \\
\cline { 2 - 4 } & average & 10.9 & 7.5 \\
\hline \multirow{4}{*}{$\begin{array}{c}\text { porosity of } \\
\text { samples(\%) }\end{array}$} & $<3$ & 0 & 11.4 \\
\cline { 2 - 4 } & $3 \sim 6$ & 17.2 & 28.6 \\
\cline { 2 - 4 } & $6 \sim 12$ & 51.4 & 51.4 \\
\cline { 2 - 4 } & $12 \sim 16$ & 11.4 & 5.7 \\
\hline
\end{tabular}

The grain limestone was more in the district, including sparite oolitic limestone, microcrystalline chondrules oolitic limestone, microcrystalline grain limestone, microcrystalline bioclast calcarenite, microcrystalline algal calcarenite, microcrystalline limestone containing bioclast algal lumps and conglomeratic bioclast limestone[4-6]. The sparite oolitic limestone, microcrystalline chondrules oolitic limestone, microcrystalline grain limestone and microcrystalline limestone containing bioclast algal lumps were the most beneficial reservoir to develop. The development of some reservoirs were very difficult to determine because of the less samples, the development of sparite oolitic limestone is the best in the existing sample, as showed in Figure2.

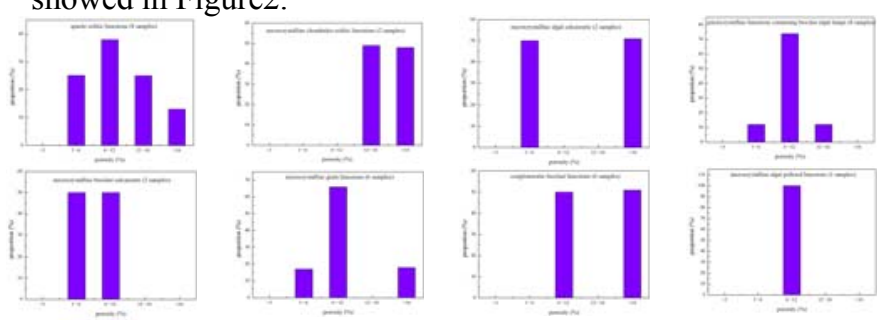

Figure 2. Proportion of porosity of grain limestone of Wells KarloffOxfordian Stage

The reservoir good for development included mainly bioclast micrite, psammitic micrite, bioclast psammitic micrite and algal spherulite micrite, which porosity was shown in Figure3.

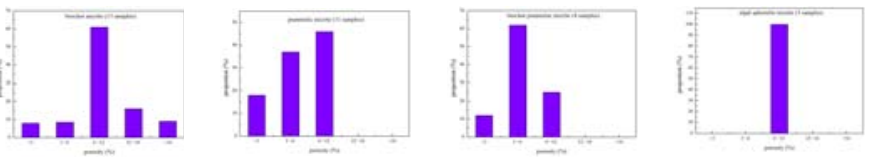

Figure 3. Histogram of porosity of granular micrite reservoir of KarloffOxfordian Stage

\section{The Relationship between Permeability and Lithology}

The permeability ranged from $0.000338 \times 10^{-3} \mu \mathrm{m}^{2}$ to $84.9332 \times 10^{-3} \mu^{2}$, the average value was $8.1127 \times 10^{-3} \mu$ $\mathrm{m}^{2}$. The main peak was less than $0.1 \times 10^{-3} \mu \mathrm{m}^{2}$ in the histogram of permeability, which accounting for $34.3 \%$ of the total sample, the samples of $0.1 \sim 1 \times 10^{-3} \mu \mathrm{m}^{2}$ accounted for $21.4 \%$, the samples of $10 \sim 100 \times 10^{-3} \mu \mathrm{m}^{2}$ accounted for $20.0 \%$, as showed in the statistical table of permeability of lithology of Oja-21 well (Table III). According to the standard of oil and gas reservoir (table I), most of the limestone was in the especially low permeability reservoir, which showed that the permeability of Oja-21well was below average.

TABLE III. STATISTICAL TABLE OF PERMEABILITY OF LITHOLOGY OF OJA-21 WELL

\begin{tabular}{|c|c|c|c|}
\hline \multicolumn{2}{|c|}{ lithology } & grain limestone & granular micrite \\
\hline \multirow{2}{*}{$\begin{array}{c}\text { permeability range } \\
\left(\times 10^{-3} \mu \mathrm{m}^{2}\right)\end{array}$} & $\min$ & 0.00163 & 0.000338 \\
\cline { 2 - 4 } & $\max$ & 84.9332 & 58.4358 \\
\cline { 2 - 4 } & average & 12.4923 & 3.7332 \\
\hline \multirow{2}{*}{$\begin{array}{c}\text { proportion of } \\
\text { lithology of sample } \\
\text { of different } \\
\text { permeability(\%) }\end{array}$} & $<0.1$ & 17.14 & 51.43 \\
\cline { 2 - 4 } & $0.1 \sim 1$ & 25.71 & 22.86 \\
\cline { 2 - 4 } & $1 \sim 10$ & 25.71 & 17.14 \\
\cline { 2 - 4 } & $10 \sim 100$ & 31.43 & 8.57 \\
\hline
\end{tabular}

In all kinds of permeability distribution (Figure4 and Table III) of different lithology of reservoir, the permeability of grain limestone was the highest, which ranged from $0.00163 \times 10^{-3} \mu \mathrm{m}^{2}$ to $84.9332 \times 10^{-3} \mu \mathrm{m}^{2}$, and the average value was $12.4923 \times 10^{-3} \mu \mathrm{m}^{2}$, the high permeability samples were mainly in range of $10 \sim 100 \times 10^{-3} \mu \mathrm{m}^{2}$ accounted for $31.43 \%$ of the total samples of grain limestone, which was most favorable reservoir to develop. The permeability of granular micrite ranged from $0.000338 \times 10^{-3} \mu \mathrm{m}^{2}$ to $58.4358 \times 10^{-3} \mu \mathrm{m}^{2}$, the average value was $3.7332 \times 10^{-3} \mu \mathrm{m}^{2}$, the samples of less than $0.1 \times 10^{-3} \mu \mathrm{m}^{2}$ accounted for $51.43 \%$ of total samples of granular micrite, and most of that was especially low permeability reservoir.
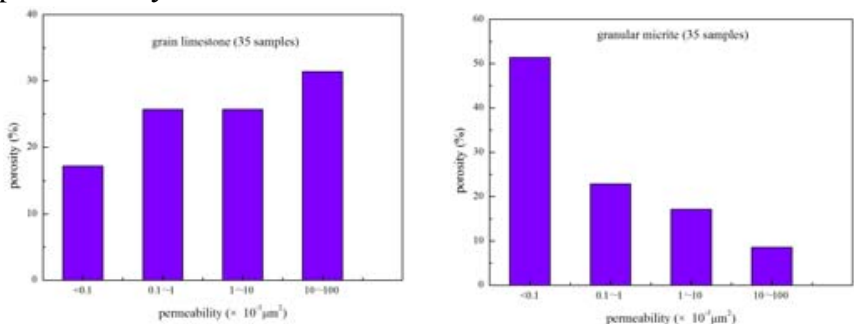

Figure 4. Histogram of permeability of reservoir of Karloff- Oxfordian Stage

The permeability of oolitic limestone, algae calcarenite, bioclast calcarenite, conglomeratic bioclast limestone and 
microcrystalline grain limestone were larger. The permeability of algal lump limestone and algal pelleted limestone were poorer. The permeability of bioclast micrite was best, and psammitic micrite came second, as shown in Figure 5 and Figure 6.

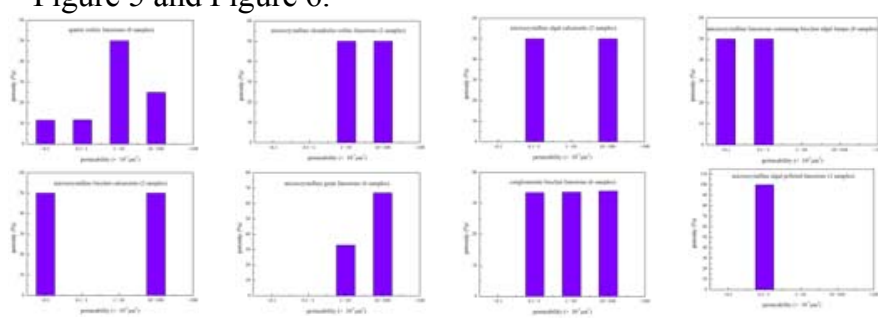

Figure 5. Histogram of permeability of grain limestone reservoir of Karloff- Oxfordian Stage

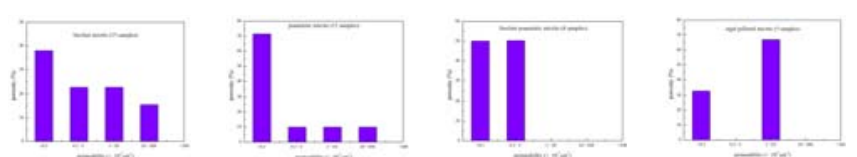

Figure 6. Histogram of permeability of granular micrite reservoir of Karloff- Oxfordian Stage

\section{The Relationship between Sedimentary Microfacies and Development of Reservoir}

Known by the above analysis of the relationship between lithology and physical property of reservoir, the reservoir quality of oolitic limestone and microcrystalline grain limestone were best, while that of algal spherulite micrite was worst. The regional distribution characteristics and the relationship between physical property of reservoir and rock type should be under the controlled of the sedimentary facies [7-8].

Because the sedimentary facies of core section of Oja-21 well was foreslope facies, the relationship between the sedimentary facies and physical property of reservoir was discussed mainly based on the analysis of the sedimentary facies and physical property of Oja-21 well. The results showed that the physical property of reservoir was under the control of the sedimentary microfacies. The relationship between sedimentary microfacies and physical property of reservoir was shown in Table IV.

TABLE IV. STATISTICAL ANALYSIS TABLE OF POROSITY AND PERMEABILITY OF SEDIMENTARY MICROFACIES

\begin{tabular}{|c|c|c|c|c|c|c|c|c|c|}
\hline \multirow{2}{*}{$\begin{array}{c}\text { sedimentary } \\
\text { facies }\end{array}$} & \multirow{2}{*}{$\begin{array}{l}\text { sedimentary } \\
\text { microfacies }\end{array}$} & \multicolumn{4}{|c|}{ porosity $(\%)$} & \multicolumn{4}{|c|}{ permeability $\left(\times 10^{-3} \mathrm{u} \mathrm{m}^{2}\right)$} \\
\hline & & samples number & $\min$ & $\max$ & average & samples number & $\min$ & $\max$ & average \\
\hline \multirow{5}{*}{$\begin{array}{l}\text { foreslope } \\
\text { facies }\end{array}$} & psammitic beach & 4 & 4.8 & 16.2 & 9.4 & 4 & 0.00563 & 42.6 & 13.4444 \\
\hline & grain banks & 15 & 4.8 & 16.6 & 9.8 & 15 & 0.00163 & 59.0 & 7.5696 \\
\hline & oolite beach & 10 & 4.1 & 21.0 & 11.6 & 10 & 0.0692 & 84.9332 & 16.3464 \\
\hline & bioherm & 6 & 7.0 & 19.0 & 13.5 & 6 & 0.152 & 15.2847 & 17.7405 \\
\hline & foreslope mud & 35 & 1.5 & 16.5 & 7.5171 & 35 & 0.000338 & 58.4358 & 3.7332 \\
\hline
\end{tabular}

Known by the analysis of porosity and permeability of sedimentary microfacies (as shown in Figure 7 and Figure 8 ), the porosity of the microfacies of bioherm ranged from $7.0 \%$ to $19.0 \%$, the average value was $13.5 \%$, which was located in the interval of $6.0 \% \sim 12.0 \%$ and $>16 \%$ in the histogram. The permeability ranged from $0.152 \times 10^{-3} \mu^{2}$ to $15.2847 \times 10^{-3} \mu \mathrm{m}^{2}$, the average value was $17.7405 \times 10^{-3} \mu \mathrm{m}^{2}$, which was located in the interval of $0.1 \sim 100 \times 10^{-3} \mu \mathrm{m}^{2}$ in the histogram. By the above data, the microfacies of bioherm of Karloff- Oxfordian Stage of Oja-21 well were the high porosity and permeability reservoir, some samples was the moderate porosity and permeability reservoir.

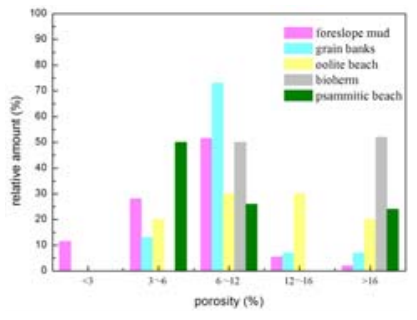

Figure 7. Porosity of sedimentary microfacies

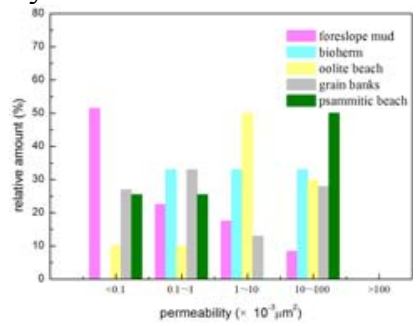

Figure 8. Permeability of sedimentary microfacies
The porosity of microfacies of psammitic beach ranged from $4.8 \%$ to $16.2 \%$, the average value was $7.5171 \%$, which was located in the interval of $3.0 \% \sim 6.0 \%$ in histogram, while the permeability ranged from $0.00563 \times 10^{-3} \mu \mathrm{m}^{2}$ to $42.6 \times 10^{-}$ ${ }^{3} \mu \mathrm{m}^{2}$, the average value was $13.4444 \times 10^{-3} \mu \mathrm{m}^{2}$, which main peak was located in the interval of $10 \times 10^{-3} \mu \mathrm{m}^{2} \sim 100 \times 10^{-3} \mu \mathrm{m}^{2}$ in histogram. Most of the samples ranged from $10 \times 10^{-3} \mu \mathrm{m}^{2}$ to $100 \times 10^{-3} \mu \mathrm{m}^{2}$ accounted for $50.0 \%$ of the total sample, the samples in the interval of $<0.1 \times 10^{-3} \mu \mathrm{m}^{2}$ and $0.1 \times 10^{-}$ ${ }^{3} \mu \mathrm{m}^{2} \sim 1 \times 10^{-3} \mu \mathrm{m}^{2}$ accounted for $25 \%$ respectively. The permeability of the facies zone was part better and part poorer, so it was low porosity and high permeability or moderate porosity and especially low permeability reservoirs.

The porosity of microfacies of foreslope mud ranged from $1.5 \%$ to $16.5 \%$, the average value was $7.5171 \%$, which was located in the interval of $0.000338 \times 10^{-}$ ${ }^{3} \mu \mathrm{m}^{2} \sim 58.4358 \times 10^{-3} \mu \mathrm{m}^{2}$, and the average value was $3.7332 \times 10^{-3} \mu \mathrm{m}^{2}$. Most of the samples were less than $0.1 \times 10^{-}$ ${ }^{3} \mu \mathrm{m}^{2}$ accounted for $51.43 \%$, and the samples in the interval of $0.1 \sim 1.0 \times 10^{-3} \mu \mathrm{m}^{2}$ accounted for $22.86 \%$. By the above data, the microfacies of foreslope mud of Karloff- Oxfordian Stage of Oja-21 well were mainly low moderate porosity and low permeability or moderate porosity and especially low permeability reservoirs. 
The porosity of microfacies of grain banks ranged from $4.8 \%$ to $16.6 \%$, the average value was $9.8 \%$, the permeability ranged from $0.00163 \times 10^{-3} \mu^{2}$ to $59.0 \times 10^{-3} \mu \mathrm{m}^{2}$, the average value was $7.5696 \times 10^{-3} \mu \mathrm{m}^{2}$. The samples which permeability was $7.5696 \times 10^{-3} \mu^{2}$ accounted for $33.33 \%$, the permeability was poor. By the above data, the microfacies of grain banks of Karloff- Oxfordian Stage of Oja-21 well were mainly moderate porosity and low permeability reservoirs.

The porosity of microfacies of oolite beach ranged from $4.1 \%$ to $21.0 \%$, the permeability ranged from $0.0692 \times 10^{-}$ ${ }^{3} \mu \mathrm{m}^{2}$ to $84.9332 \times 10^{-3} \mu \mathrm{m}^{2}$, the average value was $16.3464 \times 10^{-3} \mu^{2}$, the samples in the interval of $1.0 \times 10^{-}$ ${ }^{3} \mu \mathrm{m}^{2} \sim 10 \times 10^{-3} \mu \mathrm{m}^{2}$ accounted for $50 \%$, the permeability was better. By the above data, the microfacies of oolite beach of Karloff- Oxfordian Stage of Oja-21 well were mainly moderate - high porosity or moderate - high permeability reservoirs.

In conclusion, the carbonate reservoir quality of Oja- 21 well was under the control of the sedimentary microfacies. Oolite beach and microfacies of bioherm was good for development of reservoir. Oolite beach was best for the storage capacity, so it was the most favorable sedimentary microfacies for development of reservoir.

\section{THE HETEROGENEITY OF RESERVOIR}

The reservoir can be divided into three: intraformational, interbedded and plane heterogeneity, according to sedimentology of reservoir. The analysis of physical property change of conventional core and the section structure showed that the heterogeneity of the core section of carbonate rock reservoir of Oja-21 well was controlled mainly under lithology, sedimentary microfacies and diagenesis. From the core section, the heterogeneity of the reservoirs can be summarized into two aspects as follows.

\section{A. Interbedded Heterogeneity}

The reservoir with low porosity and low permeability interlayer could block the movement of the fluid, which caused the heterogeneity of reservoir. The interbedded heterogeneity was controlled mainly under thickness, stability and distribution of low porosity and low permeability interlayer and the differential porosity and permeability (or ratio) between compact interlayer and adjacent reservoir ${ }^{[9]}$. The quantitative parameters of the interbedded heterogeneity were the variable coefficient, the mutation coefficient, homogeneity coefficient and permeability ratio, etc., which can explain the interbedded permeability. The interbedded heterogeneity was divided into three according to these parameters: low, moderate and high heterogeneity. The variable coefficient of permeability of reservoir less than 0.5 was low heterogeneity, that of reservoir ranged from 0.5 to 0.7 was moderate heterogeneity, that of reservoir was greater than or equal to 0.7 was high heterogeneity. The mutation coefficient of permeability of reservoir less than 2 was low heterogeneity, that of reservoir ranged from 2 to 3 was moderate heterogeneity, that of reservoir greater than or equal to 3 was high heterogeneity. The permeability ratio was bigger, the heterogeneity was higher. Conversely, the heterogeneity was lower. The homogeneous coefficient of permeability ranged from 0 to 1 , the homogeneous coefficient was closer to 1 , the homogeneity was better.

The core section of Oja-21 well consisted of two layers: $\mathrm{XVp}$ and $\mathrm{XVm}$. XVp includes the first period of leaching round, second period of leaching round and third period of leaching round of the core section, consisting of 6 small layers. XVm included the third to the sixth of coring section, consisting of 17 small layers. According to the petrophysical data of $\mathrm{XVp}$ and $\mathrm{XVm}$, the interbedded heterogeneity can be evaluated by calculated permeability ratio, variable coefficient, mutation coefficient, homogeneity coefficient and differential (as shown in Table V). Contrasting these parameters with evaluation standard of heterogeneity, it was shown that the interbedded heterogeneity of XVp and XVm was high, while that of the $\mathrm{XVm}$ was stronger than that of the $\mathrm{XVp}$.

TABLE V. HETEROGENEITY PARAMETER OF INTERBEDDED HETEROGENEITY OF X V P AND X V M

\begin{tabular}{|c|c|c|}
\hline number of horizon & X V p & X V m \\
\hline average porosity $(\%)$ & 9.29 & 8.97 \\
\hline average permeability $\left(\times 10^{-3} \mu \mathrm{m}^{2}\right)$ & 9.75 & 6.86 \\
\hline variable coefficient & 0.29 & 0.31 \\
\hline mutation coefficient & 8.71 & 8.61 \\
\hline permeability ratio & 11587.1 & 221005.9 \\
\hline homogeneity coefficient & 0.11 & 0.12 \\
\hline
\end{tabular}

\section{B. In-layer Heterogeneity}

In-layer heterogeneity is the change of physical property because of the diagenesis and the fracture in the vertical control of each reservoir, it is an important factor affecting on vertical and horizontal in-layer permeability ratio and the formation of stratum containing oil, gas ${ }^{[10]}$. The quantitative parameters of the in-layer heterogeneity were also the variable coefficient, the mutation coefficient, homogeneity coefficient and permeability ratio, etc., which can explain the in-layer permeability.

According to the in-layer petrophysical data of $\mathrm{XVp}$ and $\mathrm{XVm}$, the in-layer heterogeneity was evaluated by calculated permeability ratio, variable coefficient, mutation coefficient, homogeneity coefficient and differential (as shown in Table VI). Contrasting these parameters with evaluation standard of heterogeneity, the in-layer heterogeneity of $\mathrm{XVp}$ was moderate to strong, while that of the $\mathrm{XVm}$ was stronger. 
TABLE VI. HETEROGENEITY PARAMETER OF X V P AND X V M IN LAYERS

\begin{tabular}{|c|c|c|c|c|c|c|c|}
\hline horizon & $\begin{array}{l}\text { number of } \\
\text { horizon }\end{array}$ & $\begin{array}{c}\text { average } \\
\text { porosity }(\%)\end{array}$ & $\begin{array}{c}\text { average } \\
\text { permeability }\left(\times 10^{-}\right. \\
\left.{ }^{3} \mu \mathrm{m}^{2}\right)\end{array}$ & $\begin{array}{l}\text { variable } \\
\text { coefficient }\end{array}$ & $\begin{array}{l}\text { mutation } \\
\text { coefficient }\end{array}$ & permeability ratio & $\begin{array}{c}\text { homogeneity } \\
\text { coefficient }\end{array}$ \\
\hline \multirow{5}{*}{$\mathrm{XVp}$} & 1 & 10.23 & 14.57 & 1.85 & 5.83 & 1227.36 & 0.17 \\
\hline & 2 & 16.83 & 23.44 & 0.89 & 1.89 & 17.03 & 0.53 \\
\hline & 3 & 7.93 & 10.36 & 0.26 & 1.26 & 1.69 & 0.80 \\
\hline & 4 & 5.10 & 0.19 & 0.59 & 1.59 & 35.00 & 0.63 \\
\hline & 5 & 6.34 & 0.22 & 1.10 & 2.54 & 97.87 & 0.39 \\
\hline \multirow{11}{*}{$\mathrm{XVm}$} & 8 & 11.47 & 20.27 & 0.98 & 2.91 & 27.06 & 0.34 \\
\hline & 9 & 9.37 & 23.89 & 0.67 & 1.67 & 4.99 & 0.60 \\
\hline & 10 & 11.03 & 21.49 & 0.98 & 1.98 & 114.52 & 0.50 \\
\hline & 11 & 13.52 & 17.74 & 1.47 & 4.21 & 491.45 & 0.24 \\
\hline & 12 & 9.91 & 1.39 & 0.15 & 1.15 & 1.35 & 0.87 \\
\hline & 14 & 9.70 & 0.18 & 0.97 & 3.18 & 354.60 & 0.31 \\
\hline & 15 & 12.71 & 14.34 & 1.56 & 4.08 & 969.08 & 0.25 \\
\hline & 17 & 4.85 & 0.03 & 0.79 & 2.02 & 154.44 & 0.49 \\
\hline & 18 & 5.43 & 0.04 & 0.87 & 2.39 & 11.64 & 0.42 \\
\hline & 19 & 9.34 & 0.10 & 0.06 & 1.06 & 1.13 & 0.94 \\
\hline & 20 & 8.72 & 1.96 & 1.01 & 2.39 & 359.23 & 0.42 \\
\hline
\end{tabular}

\section{THE DISCUSSION}

The Oxfordian Stage carbonate reservoir of Odjarly Gas field of Amu Darya Basin developed mainly in grain limestone, oolitic limestone and conglomeratic bioclast limestone. Lithology controlled directly the porosity of reservoir, and the porosity of grain limestone was highest. The proportion of moderate and high porosity of the grain limestone was greater than that of the granular micrite, so the reservoir performance of grain limestone was better than that of granular micrite.

The analysis showed that the carbonate reservoir quality of the Oja-21 was under the control of the sedimentary microfacies: the oolite beach and microfacies of bioherm phase of foreslope facies were favorable reservoir to develop. The physical property of oolite beach was optimal, and it was the most favorable sedimentary microfacies to develop.

The analysis showed that the heterogeneity of the core section of carbonate rock reservoir of Oja-21 well controlled mainly under lithology, sedimentary microfacies and diagenesis. As for the core section, the heterogeneity of reservoir could be summarized as interbedded heterogeneity and in-layer heterogeneity.

\section{ACKNOWLEDGMENT}

The authors wish to thank the financial support provided by Education Department Foundation (No. 2013YB112 and No. 2013YB106) and Basic Ability Ascend Projects by Younger Teachers in GuangXi University (Grant No. KY2016YB483).

\section{REFERENCES}

[1] Zhang Bing, Zhang Rongcai, Liu Henian, Wu Lei and Chen Renjin, "Characteristics of Carbonate Reservoir in Callovian-Oxfordian of
82(3), pp. 118-126

[2] $\mathrm{Xu}$ Shenglin, Chen Hongde, Lin Liangbiao and Chen Anqing, "Characteristics Of Carbonate Rock Reservoir Of Feixianguan Formation In Southeastern Sichuan Basin," Fault-Block Oil \& Gas Field, vol. 17(1), pp. 19-23.

[3] Fan Jiasong and $\mathrm{Wu}$ Yasheng. "Restudies on permian reefs in eastern sichuan, china," Oil \& Gas Geology, vol. 23(1), pp. 12-18.

[4] Liu Zhongbao, Sun Hua, Yu Bin-Song, Wang Zengxiang And Yang Shengbin, "The Control Of Fr Actur Es On Kar St In Ordovician Carbonate Reservoirs In Tazhong Ar Ea," Xinjiang Petroleum Geology, vol. 28(3), 2007, pp. 289-291.

[5] Ma yongsheng, Mu chuanlong, Guo xusheng, Tan qinyin and Yu qian. "Characteristic and framework of the changxingian sedimentation in the northeastern sichuan basin," geological review, vol. 52(1), pp. 2529.

[6] Wang Qiying, Li Cailiang, Wang Dajun and Li Hong, "Study Of Controlling Factors And Accumulation Condition Of Oolitic Beach Gas Reservoir In Feixianguan Formation In The East Of Sichuan," Offshore Oil, vol. 27(3), 2007, pp. 64-69.

[7] Thomas Meisel, Urs Krahenbuhl and Michael A.Nazarov, "Combined Osmium And Strontium Isotopic Study Of The Cretaceous-Tertiary Boundary At Sumbar,Turkmenistan: A Test For An Impact Vs.A Volcanic Hypothesis.” Geology, (5), April 1995, pp. 313-316.

[8] Dravis J J., "Deep-Burial Microporosity in Upper Jurassic Haynesville Oolitic Grainstones, East Texas," Sedimentary Geology, vol. 63,1989 , pp. 325-341.

[9] Zhao YongGang, Li GongQiang, Song LiZhi and Sun YanFei, "Application of Logging Data in Identifying Carbonate Reservoir Types in The Daniudi Gas Field," Natural Gas Industry, vol. 28(12), 2008, pp. 44-48.

[10] Hang bing, Zheng RongCai, Wen HuaGuo, Hu ZhongGui, Luo AiJun, Wen QiBing and Zhu YiXin. "Identification Criteria and Prediction of Reef And Shoal Facies Reservoirs of the Changxing Formation in the Eastern Kaijiang-Liangping Area Intraplatform Trough," Geological Journal Of China Universities, vol. 15(2), 2009, pp. 273284. 